\title{
Understanding the Stability of Early Iron Age folks of South India with Special Reference to Krishna-Tungabhadra- Kaveri, Karnataka; Their Past-Present-Future
}

Arjun $R^{*}$

\section{Abstract}

There are about 1933 Early Iron Age Megalithic sites spread across South India. The Early Iron Age of South India is implicit either in the form of burial sites, habitation sites, habitation cum burial sites, Iron Age rock art sites, and isolated iron smelting localities near a habitation or burials. This paper is an attempt to take a rough computation of the potentiality of the labour, technology and quantity of artifact output that this cultural phase might have once had, in micro or in macro level. Considering the emergence of technology and its enormous output in Ceramics, Agriculture, Metallurgy and Building up Burials as industries by themselves, that has economic, ethnographic and socio-technique archaeological imprints. This helps in understanding two aspects: one, whether they were nomadic, semi settled or settled at one location; two, the Diffusion versus Indigenous development. A continuity of late Neolithic phase is seen into Early Iron Age and amalgamation of Early Iron Age with the Early Historic Period as evident in the sites like Maski, Brahmagiri, Sanganakallu, Tekkalakota, T-Narasipur. In few cases, Iron Age folks migrated from one location to the other and settled on the river banks in large scale like that in Hallur and Koppa. In

Ph.D Research Scholar, Ancient Indian History Culture and Archaeology, Deccan Collage Post Graduate and Research Institute, Pune, India; E-mail: arjunrao93@gmail.com 
rare cases, they preferred to climb up the hill and stay on the rocky flat surface for example Aihole and Hiere Bekal- sites which are located close to or on the banks of the river or its tributaries of Krishna-TungabhadraKaveri.

Keywords: Labour, Industry, Production, Megaliths, Nomadic, Semi Settled, Early Iron Age.

\section{Introduction}

The Grave Goods in the Megalithic Burials are "The Material Archives Preserved in the Burial Monuments". We have More than fifty 14C dates available so far for Megalithic sites; the burials with grave furniture were erected from $c .1200 \mathrm{BCE}$ and continued till about c. 400 CE (Deo 1973, 1982, 1991; Moorti 1994; Rajan 1993, 2004; Mohanty and Selva Kumar 2002; Sundara 1973; Possehl 1988, 1994). The mystifying question about Megalithic population has been due to the scantiness of settlement sites. While there are hundreds of burial sites, only a few habitation sites have been discovered. Early Iron Age Investigation is still a legacy of studying and understanding the burials, their typology and grave furniture. We have not concentrated much on tracing their habitation locations as well as resource points. There is lack of recognising habitation at a large number of places in comparison to the burial sites due to systematic and intensive regional surveys (Mohanty 1993-4). With this background, it was assumed by several archaeologists that the population was probably pastoral, nomadic or semi-settled agriculturalists. But on the other hand conflicting opinions were also formed. Alexander Rea extensively did excavation and exploration on early Iron Age megalithic sites in Adichannallur area; he observes that there are more habitation sites than burial sites (Rea 1902). B K, Thapar investigating in Maski, proposed that the Megalithic people were settled agriculturalists and had a bias for urbanization (Thapar 1957). But such arguments were not well established or did not attract much attention.

To understand the material culture of Megalithic South Indian Iron Age in general and Deccan and lower Deccan regions of Karnataka in particular, an attempt has been made to trace or classify the types of industries, based on the artifact types. This invariably 
helps in understanding the amount of labour, industry and their respective production, market demand, the settlement stability or attempts for settled way of life. Through Economic Archaeological Imprints an attempt has also been made to trace or classify the types of industries, which will in turn substantiate different types of artifacts. It also gives sway to the rough computation on the quantity of output from this cultural industry in micro or in macro level. All these are based on the,

i. Number of identified burial monuments

ii. Explored and excavated sites that substantiated the metal smelting furnaces and the habitation

iii. Archaeologists' arguments on the identification of regional centers and the calculation of average population

Table 1 : State wise Breakup of Megalithic Sites of South India (Moorti 1994)

\begin{tabular}{|l|l|l|l|l|l|l|l|l|l|l|}
\hline A. & B. & C. & D. & E. & F. & G. & H. & I. & J. & K. \\
\hline Maharashtra & 63 & 8 & 23 & 3 & 3 & - & - & 4 & 7 & 91 \\
\hline Andhra Pradesh & 168 & 25 & 3 & 10 & 33 & - & 2 & 15 & 44 & 300 \\
\hline Karnataka & 429 & 25 & 40 & 29 & 69 & 3 & 1 & 35 & 33 & 665 \\
\hline $\begin{array}{l}\text { Tamilnadu including } \\
\text { Pondicherry }\end{array}$ & 423 & 68 & 3 & 19 & 51 & 3 & - & 13 & 27 & 607 \\
\hline Kerala & 196 & 73 & - & - & - & 1 & - & - & - & 270 \\
\hline Grand total & $\mathbf{1 2 5 9}$ & $\mathbf{1 9 9}$ & $\mathbf{6 5}$ & $\mathbf{6 5}$ & $\mathbf{1 5 6}$ & $\mathbf{7}$ & $\mathbf{3}$ & $\mathbf{6 6}$ & $\mathbf{1 1 2}$ & $\mathbf{1 9 3 3}$ \\
\hline
\end{tabular}

a. Name of the state

b. Burial site

c. Burial/memorial sites

d. Habitation / burial sites

e. Habitation sites (?)

f. Habitation cum burial sites (?)

g. Iron age painting sites

h. Isolated iron smelting localities near a habitation / burial site

i. Habitation sites

j. Habitation cum burial sites

k. Total no. of sites 
In this culture, we come across mainly four industries based on the evidences supplied by the burial monuments, metal furnace sites and the habitation sites.

i. Ceramic Industry

ii. The Industry of Metallurgy

iii. Monument Builders

iv. Subsistent Strategy

What is 'Industry' in the Archaeology discipline? "A collection of artifacts of one category at a site is called as an industry". The potteries of a site can together be called ceramic industry, like wise bead industry, stone tool industry. Of this culture, two new additions can be made which are parts of their inventions -metallurgy and burial builders. Though the discovery of metal smelting furnaces is scarce, the metal products are relatively very dense and advanced. Digging burial pits, collecting, dressing and transporting stones from nearby the available rock formations is also an industry.

There are certain features to be observed

1. The ceramic industry takes place where people habituate. In addition, this involves selective compulsion of time. Therefore ceramic industry moves along with the people or with group's movement.

2. The metal furnaces involve the infrastructural set up. Therefore, it is the defined location, which involves welldefined selective compulsion of time. In addition, in this sense, the group who worked in this industry, the possibility of them being semi- nomadic is hard to debate.

3. The custom of erecting gigantic burial monuments and their utility for disposal of the dead in the particular locality is a result of a defined search based on the availability of raw materials. It shows not only their well-defined mind behind the selection of locality, but also sound planning for the movement of labor, extraction of raw stones and grave furnishers. Whether short or long distance, in most of the Karnataka's megalithic sites, their habitation outskirts are marked either by riverbank, rock formations or hills and in many cases both as is evident in Koppa (Arjun 2014b). 
4. Among all the above three features, there are common industrial factors; land, labor, raw materials, technology and economic operation. It appears that all the abovementioned three industries were clearly demarcated, having a common utilitarian orientation. It is clear that commodity exchange value or currency value was subjected or defined mainly on labour \& economic operation or production. Land, raw material and technology are natural and cognitive sources that could not be monopolized, because to monopolize there comes the need for political operation or leadership operation and there is no direct evidence apart from Technomic, Socio-Technic and Ideo-Technic artifact study perspective that speaks about the existence of political institution or political operation in the megalithic South Indian Iron Age.

\section{Ceramic Industry}

The well-known ware of the period is black and red ware, produced by the inverted firing technique. The other types are red ware, slipped ware, kaolin painted russet ware coated that were domestic in utility and in addition to them urns and sarcophagi were produced for funeral purposes. To produce these varieties there is need for skilled hands because it's not just being artistic. Along with art it involves scientific technological process and selective compression of time for extraction of clay, production, post production and make it ready for the supply.

The black and red ware was manufactured in reduced combustion, due to non-oxidization it turns black all over. The red ware is sometimes slipped in brighter material. Kaolin painted russet coated ware are similar to the red ware in texture and fabric, but are covered with russet coating before firing and the pot was painted by kaolin all over in linear patterns. All these different types of potteries are characterized by fine fabric, produced from well lavigated clay rarely with sand or such gritty material used as degraissant. They were usually well fired in open kilns in low temperature. Mortimer Wheeler thinks that they were turned on a slow wheel; no doubt, larger vessels are handmade. The pottery is 
generally slipped in the same colored material and it is often burnished to a high degree, resulting in finely polished surface.

The majority of the pots, especially those from graves in south India, were of high quality with a fine polished surface. The funerary receptacles like the urns and sarcophagi were thick in section of a coarse texture, often moderately or even ill fired, though well-burnt urns were not altogether unknown. Small pieces of straws were mixed with the clay to act as binding material. The sarcophagi were generally provided with short legs, often hollow, pierced with a hole on the sides. Both the urns and the sarcophagi were provided with the lids covering the shoulder.

They produced vessels to serve as tableware, for eating and drinking purpose. The cooking utensils were thicker sections and sometimes had an intentionally roughed lower part, to place on the ovens or on earth. The upper parts being highly finished, frequently with carination at the shoulder and a variety of the shapes of rims; the storage jars of different sizes and shapes, to be used either in the kitchen or for preserving grains etc., or the burial urns and sarcophagi, to collect the grave furnishers. Thus, the potter of those days was skilled in manufacturing various kinds of vessels. The shapes of the vessels have undergone an evolutionary change from stage to stage and had become elongated and pointed bottom, requiring supports or stands on which to stand. They produced different types of ring stands, a squat type, and an elongated type with a narrow or concave middle and flaring lower and upper ends, terminating in flaring beaded or folded rims, with an hourglass section. Pedestal and footed vessels were also produced in good numbers. To cover those vessels, lids were made in various shapes; the lid-cum-bowl represents highly evolved and complex types. These vessels were also sometimes provided with spouts, lugs or lips. The vessels have been incised with one or two grooves on the upper part of the body, on the shoulder, neck or the rim portion.

Uncommonly, potteries of appliqué designs with painting in a white pigment or in white, yellow kaolin, or even in red ochre are also found. They designed with horizontal lines, single or multiple , being parallel when multiple, curvilinear or wavy lines, intersecting lines, single or parallel double lines cutting each other 
so as to form triangles, square or lozenges, oblique strokes, circles, semicircles, concentric or intersecting and dotted patterns .

It seems that during the period the profession of pottery was in a very good demand. Because, as is evident from the archaeological investigations, the metal utensils were very rare and these potteries meet a variety of purposes, ranging from crockery, commodity storage, water storage, urns, burial urns, sarcophagi, for ritual purposes and for deposition in the graves. Some unique and aberrant types of vessels have also been found, for example, the zoomorphic urns like elephantoid specimens from Perumbair and from a site on the left bank of the Tungabhadra, opposite the town of Hampasagara (Nagaraja Rao 1972: 258). Robert Bruce Foote exhibited the ground shaped vessels; the horn shaped ones - called seed boxes by him, which illustrates the high degree of skill possessed by the potter. Firing the large bath-tub-like coffins or the zoomorphic receptacles had to be done with great care because of their large size and often, vent holes were provided for the evasion of gases while being burnt. The pots from the burials exhibited highly advanced and variegated shapes than those in the habitation sites.

\section{The Industry of Metallurgy}

The minerals and ores in the peninsula are not distributed in a uniform manner. Humankind at this juncture went in for a bold experimentation in the use of metals that shaped the destiny of its cultural development. Use of copper and gold was known to the late phase of Neolithic South India (early Iron Age comes next in the chronology). The furnace sites alone are very sparse in notice, but the habitation sites have yielded evidence for iron smelting in the form of furnaces, slag, ore and terracotta pipes (tuyeres), crucible fragments, etc. (Gogte 1982b; Gururaja Rao 1972; Leshnik 1974; Dhavalikar 1968; Moorti 1994). But it is clear that they employed objects of iron, copper, gold and bronze. 
Table 2: Quantitative Distribution of Megalithic Sites in Relation to Metals and Minerals (Moorti, U.S 1994: 15)

\begin{tabular}{|l|c|c|c|}
\hline Metals and Minerals & $\begin{array}{c}\text { Habitation } \\
\text { sites }\end{array}$ & $\begin{array}{c}\text { Burial } \\
\text { sites }\end{array}$ & $\begin{array}{c}\text { Habitation cum } \\
\text { Burial Sites }\end{array}$ \\
\hline Metals & 7 & 148 & 22 \\
\hline Gold & 18 & 300 & 52 \\
\hline Iron & 8 & 67 & 9 \\
\hline copper & 1 & 37 & 9 \\
\hline Lead, zinc and silver & Minerals \\
\hline \multicolumn{3}{|c|}{} \\
\hline Steatite & 5 & 12 & 8 \\
\hline Dolomite & - & 1 & 1 \\
\hline Mica & 7 & 76 & 2 \\
\hline Ochre & 2 & 122 & 9 \\
\hline Feldspar & 2 & 20 & 3 \\
\hline Magnesite & 11 & 36 & 2 \\
\hline \multicolumn{4}{|l|}{ Abrasive \& gemstones } \\
\hline Gamet & 3 & 19 & 4 \\
\hline Beryl & - & - & - \\
\hline $\begin{array}{l}\text { Sites with no } \\
\text { Mineral/Ore Resource } \\
\text { Nearby }\end{array}$ & 55 & 814 & 163 \\
\hline
\end{tabular}

Particularly iron was majorly smelted in diverse shape and size for the production of tools, weapons, and implements for agriculture, construction, hunting and for house hold utilities. Copper and bronze were used to manufacture artefacts such as horse ornaments, bangles, rings, bowls, bells, iron daggers with copper handles, etc. (Deo 1970, 1985; Gururaja Rao 1972; Leshnik 1974). Though bronze was known, it was used in very limited scale. The grave goods consisting of objects of metal other than Iron, is very meagerly found across the culture. Therefore, the relative density and types of metal smelted for the production may not only indicate the demand and supply but it also helps to understand how much close they were to the respective ores. Copper, gold, bronze are soft metals in contrast to iron; indicates that during this period there happened intensified production activities and hence the hard tools, implements and weapons became very essential. The market demand has the ability to extract the ore or to import (domestic) from one region to other and hence large diffusion is 54 
evident in metal objects in the absence of good number of furnaces found. Archaeologists must investigate also from such perspectives.

No doubt next to the ceramic industry, the industry of metallurgy was an important part of the economic order. The examination of Iron objects from the burials, by Archaeologists and Chemists attests that the blacksmith possessed high degree of skills in production of iron objects. Some of the dagger blades and spear heads, leaf shaped with thin edges, but strengthened by the mid rib, the detachable ring-fasteners of the axes, the all- metal spears or pikes, short swords with midribs and such other types of implements bespeak of an advanced technology (Rao 1972). In about c. 450 BCE Ktesias mentioned two fine steel swords presented to Ataxerxes Mnemon, the Persian king and he traced these steel swords to India. This shows that the Indian smiths had mastered the technology of smelting iron so well that Indian steel had a reputation for its excellence even among the foreign royalty. Probably, the South Indian megalithic builders whose iron implements and weapons far outnumbered and excelled in quality, of those of any other Indian community must also have known this process of producing high quality steel. The iron samples collected from Komaranahalli and Tadakanahalli, Karnataka was undertaken to understand various aspects of metallurgy. These studies have revealed that the iron objects have more than 98 per cent pure iron (Deo 1985: 22 ; Gururaja Rao 1970; Agrawal et al. 1980-1 ; Gogte et al. 1984; Deo 1985; Biswas 1996: 225-33; Swamy 1996). In this connection, it is only proper to recall that a remarkable process of manufacturing steel was known to the south Indians at a very early date and it probably originated among them.

\section{Burial Builders}

Almost certainly, it is unconstrained to accept that the early Iron Age megalithic burial builders used natural stone ensuring the strength and the durability. Megalithic folks were the second architects in southern India. The first architects were of the late Neolithic folks who constructed their houses in wattle and doab as substantiated in the Brahmagiri (Wheeler 1948), Sanganakallu (Ansari 1969), Tekkalakota (Sankalia 1963-64: 24) and Piklihal 
(Allchin 1960) excavations, Karnataka. Erecting a structure or memorial posts over the burials were the very first development in South Indian cultural context. The evidence for transformation of structural usage of space from secular- ritual is clearly evident (Arjun, 2014a).

At every stage for erecting the burial of any architectural typology, searching, selecting and quarrying of stones to transporting them to the burial location and roughly dressing them involves labour and time of skilled group of individuals. They were adept in handling almost every kind of rocks available in north Karnataka. But it doesn't mean that the architectural type of tomb depended on the geological zones or type of rocks available, rather, the different tomb types are due to the traditional affiliations.

But when we attempt to study the correlation between the availability of suitable rock materials and the occurrence of funerary monument type: it is understood that geology played its role in location patterning of the site rather with burial typology. For example, the location of Hallur (Dharwar district, north Karnataka) and Koppa (Mysore district, south Karnataka) can be cited. At Hallur, the habitation site is on the left bank of the Tungabhadra river and the cemetery sites are located $5 \mathrm{~km}$ away at Bhairavanpada and $3 \mathrm{~km}$ west of Hallur respectively where the raw material was available for the construction of burial monuments (Nagaraja Rao 1971). Koppa, habitation cum burial site is located a mile away from the right bank of river Kaveri and at the foot of dolerite rock formation of about $20-30 \mathrm{~m}$ high and about $700 \mathrm{~m}$ in stretch (presently). The stones for burials are extracted from these rock formations and they habituated to the immediate south of stone formation (Arjun 2013, 2014b). Early Iron Age burials are found on a rocky hill surface, on slopes, in foot hill, on plain land, in river banks etc. In simple words two factors are clear; firstly, the existing burial customs decided the type of burial monuments to be built and not the geology of the area (Moorti 1994:15). Secondly, in my view, behind the selection of burial spot there is some sort of skilled character that has worked in the background of ritual or customs and they were distinct group of people (among the regional early iron age megalithic folks) whose profession was burial construction and hence it is an industry by itself. 


\section{Subsistence Strategy}

Studies carried out so far on the subsistence strategies practiced during the megalithic period of South India have rather been vague. Opinions vary on the nature of economy prevalent in the megalithic communities ranging from agriculture to pastoralism. Scholars suggest the gradual transformation from a semi-nomadic economy to sedentary economy during early to late Iron Age phase. Although the environmental factor has been considered as a crucial determinant in deciding the nature of subsistence economy, the open avenue of alternative strategies available for a cultural group cannot be ignored. Environmental and cultural factors determine the cost functions of production where a human group has a decided advantage in making a selection between alternative strategies that result in a stable subsistence mix. The cost curve model presented by Earle, while dealing with subsistence economy and change, hypothesize that "producer's asses the costs and yields of the available procurement strategies and then select the strategy mix that minimize cost while fulfilling subsistence requirements" (Earle 1980: 4)

In this background Higgs classified subsistence economies into

- Mobile (Hunting- Gatherer and Pastoral)

- Sedentary (Agriculture)

- Mobile cum Sedentary (Pastoral cum Agriculture)

The available archaeo-botanical evidences are well studied, reviewed and also they are compared with governing factors such as altitude, soil type and present day average annual rainfall to understand physiographic setting. The studied samples are: Rice grains (Oryza sativa) and Ragi (Eleusine coracana) from Koppa (Kajale 1997) and Jadigenahalli (Sheshadri 1960); Hyacinth Bean, Millet (Setaria) Wheat (Triticum spp), Koddo Millet (Paspalum scrobiculatum), Horse Gram (Macrotyloma uniflorum), Black Gram (Vigna mungo) from Hallur (Vishnu-Mittre 1971; Kajale 1988-9); Hyacinth Bean, Green Gram (Vigna radiate) from Veerapuram (Kajale 1984); Cotton from T. Narasipura (Swamy 1971). Barley (Hordeum vulgare L.) form Savandurga. Green Gram (Vigna radiate) from Vidharbha sites. It shows that they had intensive agricultural 
activity as a part of their life. Ragi is one of the hardiest of the crop suited for dry farming and rice for wet farming; both types of cultivations were followed, and even today rice and ragi both are staple food not only in Karnataka, also in other southern Indian states.

\section{Conclusion}

The Early Iron Age folks were not nomadic or semi settled, at least not of the large sites. In few geographical locations, the iron producing folks i.e. early Iron Age folks abandoned the granite hilltop settlement where their antecedent copper producing late Neolithic folks lived and came down to foot hill and on open land as seen in Maski, Brahmagiri, Sanganakallu. Neolithic folks who lived on river bank, among them few iron producing folks continued to stay on the same river banks like in Hallur and TNarasipura. In few cases, Iron Age folks migrated from one location to the other and settled on the river bank in large scale like that in Koppa. In rare cases, they preferred to climb up the hill and stay on the rocky flat surface as in Aihole, Hienekal etc.

But on the other hand, the settlement for the long period was also not possible may be due to the impact of urbanization followed by the establishment of early princely states and their regional administrative centers in the south. Mauryas and Sathavahanas had made their presence in Isila (Brahmagiri). On the one side these megalithic people were still in the state of graffiti expression, whereas on the other hand in the urban centers Brahmi script was developed to the level of expressing the language. Asokan edicts at Brahmagiri, Maski, Jattangi Ramesgwara etc., are testimonial of 'communication through script to general public'. More interestingly they are not only early Iron Age sites but also Neolithic sites too.

What does it mean? The literate society or community already had a line of communication with early Iron Age folks and they tried to infiltrate the urban essence or urban migration into the preliterate early Iron Age people and the locations. The possible link of communication among them primarily would be the economic transaction. The Early Iron Age folks having such a large as well as diversified artifact production for basic needs as well as for day to 
day activities, firstly ensured stability and secondly the contact with urban centers where there products might have been supplied to.

As a result of communication of Early Iron Age folks with the urban centers, there might have occurred urban infiltration into early Iron Age locations. As a testimonial we have evidence of Ashokan edicts, relief panel of Ashoka (reign 269-232 BCE), Buddhist Stupas in Amravati style of Sathavahana period, half a dozen of Roman Denarii of Augustus (minted c. 2 BCE- c. 11 CE) and of Tiberius (Minted c. 27-37 CE) had entered Maski, Kanaganahalli, Brahmagiri and Chandravalli during c. $3^{\text {rd }}$ century BCE - $1^{\text {st }}$ century CE. It has been suggested that these people (Early Iron Age) were responsible for the construction of tanks and introduction of tank irrigation system in south India (Banerjee 1956) An early historical treatise, Kautilya's Arthashastra gives copious information regarding construction of dams, canals and management of canal water, levying of tax (Kangle 1963). Smith (1856) gives a list of earth dams constructed in the $2^{\text {nd }}$ century to $3^{\text {rd }}$ century BCE in South India.

It is clear that, at least in the large sites like Sanganakallu, Brahmagiri, Chandravalli, Maski, Kanaganahalli, Tekkalakota, etc., the early Iron Age folks had their past i.e. Neolithic folks. They learnt the art of smelting, pottery manufacturing, agriculture and the consciousness of disposing the dead where the Neolithic folks disposed their dead in urn and buried in hut floors and in habitation area. They developed the skills to the level of technology and industry. The early Iron Age folks foresaw their future with early historic people or vice versa to get into the Monarchical System. But what happened later on?

\section{Reference}

Agrawal, O. P, Harinarain \& Bhatia S K. (1980-1). Technical Studies of Iron Implements from the Megalithic Site of Tadakanahalli, Puratattva 12, 97-100.

Allchin, F. R. (1955). Archaeological Sites in the Benkal Forest, Hyderabad. Man. 60.

Allchin, F. R. (1960). Piklihal Excavations. Hyderabad: Andhra Pradesh Government Publications, Archaeological Series No. 1. 
Ansari, Z. D. \& Nagaraja Rao, M S. (1969). Excavations at Sanganakallu1964-65. Pune: Deccan College.

Arjun, R. (2013). Megalithic Culture of Karnataka with Special Reference to Koppa and a Study on Vibrant Cultural Aspects, MPhil Dissertation, Mysore: University of Mysore.

Arjun, R. (2014a). Architecture of Karnataka: The Antiquity and the Transformation (From Tekkalakota to Pattadkal), Mysociety VIII (1-2), 26-44.

Arjun, R. (2014b). Reinvestigating Koppa South Indian Megalithic Burial Site: Addressing Iron Age Habitation Problem. Arnav.

Biswas, A. K. \& Biswas S. (1996). Minerals and Metals in Ancient India. New Delhi: D K Print World.

Deo, S. B. (1982). The Vidarbha Megaliths-A review, BDCRI 41, 27-32.

Deo, S. B. (1973). The Dating of Megaliths in Maharashtra: Evaluation of Some New Evidence, in D P Agrawal and A Ghosh (Eds.), Radiocarbon Dating and Indian Archaeology (pp. 131-7), Bombay: Tata Institute of Fundamental Research.

Deo, .S B. (1982a). Recent Researches on the Chalcolithic and Megalithic Culture of the Deccan. Madras: University of Madras.

Deo, S. B. (1985). The Megaliths: Their Culture, Ecology, Economy and Technology, in S B Deo \& K Paddayya (Eds.), Recent Advances in Indian Archaeology (pp. 89-99), Pune: Deccan College.

Deo, S. B. (1991). New Discoveries of Iron Age in India, in C Margabandhu, K S Ramachandran, A P Sagar \& D K Sinha (Eds.) Indian Archaeological Heritage,189-98. Delhi: Agam Kala.

Devaraj, D. V. Joshi, N. V., Patil \& Gangadhara, T. S. (1996). Heggadehalli A Report on Megalithic Excavations: 1995. Mysore: Directorate of Archaeology and Museums.

Dhavalikar, M. K. (1968). A Plough Coulter from Brahmagiri-India, Antiquity 42, 137-8

Gogte, V. D. (1982). Megalithic Iron Smelting at Naikund (Part II: Efficiency of Iron Smelting by Chemical Analysis), in S B Deo and A P Lamkhedkar (Eds.) Excavations at Naikund 1978-80, 56-9. Bombay: Department of Archaeology and Museums.

Gogte, Y. D. Bhoraskar Y. N. \& Lahoti P. S. (1984). 14Me V Neutron Activation Analysis of Megalithic Iron Objects. Bulletin of the Deccan College Research Institute 43, 49-52.

Gururaja Rao, B. K. (1970). Development of Technology during the Iron Age in South India: C. 1000 BC to the Beginning of Historical Times. Indian Journal of Historical Sciences 5(2), 253-71.

Gururaja Rao, B. K. (1972). Megalithic Culture of South India. Mysore: Prasaranga University of Mysore. 
Kajale, M. D. (1984). New Light on Agricultural Economy during the First Millennium B.C.- Palaeobotanical Study of Plant Remains from Excavations at Veerapuram, District Kurnool, Andhra Pradesh, in T V G Sastri, M Kasturi Bai \& J Vara Prasada Rao (Eds.), Veerapuram-Type Site for Cultural Study in the Krishna Valley. Hyderabad: Birla Archaeological and Cultural Research Institute.

Kajale, M. D. (1988-9). Ancient Grains from Excavations at Hallur (1976 Season), District Dharwar, Karnataka. Bulletin of the Deccan College Post-Graduate and Research Institute 48-9: 123-8.

Kajale, M. D. (1997). Evidence of Rice (Oryza Sativa Linn.) from Koppa, Megalithic Site in Karnataka. Man and Environment XXII (1), 97-102.

Krishna, M. H. (1931). Excavations at Chandravalli. Mysore: Directorate of Archaeology and Museums.

Krishnaswami, V. D. (1949). Megalithic Types of South India, Ancient India $5,35-45$.

Leshnik, L. S. (1974). South Indian 'Megalithic' Burials: the Pandukal Complex. Wiesbaden: Franz Steiner Verlag GmbhH.

Mohanty, R. K. \& Selvakumar, V. (2002). The Archaeology of the Megaliths in India: 1947-1997, in Settar, S \& Korisettar, R (Eds.) Indian Archaeology in Retrospect, Volume I, Prehistory, Archaeology of South Asia. New Delhi: Indian Council of Historical Research \& Manohar Publishers.

Mohanty, R. K. \& Walimbe S. R. (1993). A Demographic Approach to the Vidarbha Megalithic Culture. Man and Environment XVIII (2), 93-103.

Moorti, U. S. (1986). Megalithic Culture of South India: Socio-Economic Perspectives. Varanasi: Ganga Kaveri Publishing House.

Moorti, U. S. (1990). Megalithic Karnataka -A Location Analysis, in A Sundara (Ed.), Archaeology in Karnataka. Mysore: Directorate of Archaeology and Museums.

Mudhol, M. S. (1997). A Technical Study of Megalithic Metal Objects. Mysore: Directorate of Archaeology and Museums.

Nagaraja Rao, M. S. (1971). Protohistoric Cultures of Tungabhadra valley : A Report on Hallur Excavations . Dharwar: Published by the Author.

Nagaraja Rao, M. S. \& Malhotra, K. C. (1965). Stone Age Hill Dwellers of Tekkalakota. Pune: Deccan College.

Nath, B. (1957). Animal remains from Maski, Ancient India 13, 121-9.

Possehl, G. L. (1988). Radiocarbon Dates from South Asia, Man and Environment XII, 169-96.

Possehl, G. L. (1994). Scientific Dates for South Asian Archaeology. Pennsylvania: University of Pennsylvania.

Rajan, K. \& Yateeskumar V. P. (2013). New Evidences on Scientific Dates for Brahmi Script as Revealed from Porunthal \& Kodumanal Excavations. Pragdhara, 21-22, 279-295. 
Rea, A. (1902-03). Prehistoric Antiquities in Tinnevelly. Annual Report of the Archaeological Survey of India, 111-140.

Sankalia H. D. \& Nagaraja Rao, M. S. (1963-6). IAR, 24.

Sheshadri, M. (1960). Report 011 the Jadigenahalli Megalithic Excavations for the Year 1957. Mysore: Directorate of Archaeology, Government of Mysore.

Sheshadri, M. (1960). Report on the Jadigenahalli Megalithic Excavations for the year 1957. Mysore: Directorate of Archaeology and Museums.

Subbayya, K. K. (1990). New Light on the Megalithic Excavations at Heggadehalli and Koppa, in Sundara, A. (Ed.), Archaeology in Karnataka. Mysore: Directorate of Archaeology and Museums.

Sundara, A. (1973). Chronological Order of Megalithic Tombs Types in Karnataka, in D P Agarwal \& A Gosh (Eds.), Radio Carbon and Archaeology (pp. 239-51). Bombay: Tata institute of Fundamental Research.

Swamy, B. G. L. (1971). Wood Remians from the Excavations at T. Narasipur, in Report of the Excavations at T. Narasipur. Bangalore: Government Press.

Swamy, L. N. (1996). Ancient Smelting and Forging Furnaces, in K V Ramesh, V Shivananda, M Sampath \& L N Swamy (Eds.), Gauravam: Recent Researches in Indology. New Delhi: Harman Publishing House.

Taylor, M. (1841). Megalithic Tombs and other Ancient Remains in the Dekhan. Hyderabad: Department of Archaeology.

Thapar, B. K. (1957). Maski 1954: A Chalcolithic Site in the Tapti Valley, Ancient India 20, 5-167.

Vishnu-Mitre. (1971). Ancient Plant Economy at Hallur, in Prehistoric Cultures of the Tungabhadra Valley - A report on Hallur Excavations. Dharwar: Published by the Author.

Vishnu-Mitre. (1971). Ancient Plant Economy at Hallur, in M S Nagaraja Rao (Ed.), Protohistoric Cultures of the Tungabhadra Valley-A Report on Hallur Excavations. Dharwad: Published by the Author.

Wheeler, R. E. M. (1947). Brahmagiri and Chandravalli: Megalithic and other Cultures in the Chitaldrug District, Mysore State, Ancient India IV. 